U.S. Dept. of Interior Geological Survey Denver, Colorado

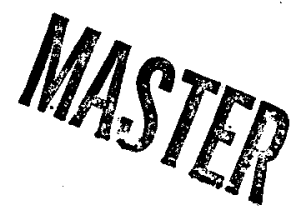

\title{
Interpretation of Electromagnetic Soundings \\ In the Raft River Geothermal \\ Area, Idaho
}

\author{
by \\ Walter $i$. Anderson \\ OPEN-FILE REPORT NO. 77-557
}

1977

This report is preliminary and has not been edited or reviewed for conformity with U.S. Geological Survey standards. 


\section{DISCLAIMER}

This report was prepared as an account of work sponsored by an agency of the United States Government. Neither the United States Government nor any agency Thereof, nor any of their employees, makes any warranty, express or implied, or assumes any legal liability or responsibility for the accuracy, completeness, or usefulness of any information, apparatus, product, or process disclosed, or represents that its use would not infringe privately owned rights. Reference herein to any specific commercial product, process, or service by trade name, trademark, manufacturer, or otherwise does not necessarily constitute or imply its endorsement, recommendation, or favoring by the United States Government or any agency thereof. The views and opinions of authors expressed herein do not necessarily state or reflect those of the United States Government or any agency thereof. 


\section{DISCLAIMER}

Portions of this document may be illegible in electronic image products. Images are produced from the best available original document. 
Interpretation of Electromagnetic Soundings

1n the Raft River Geothermal

Area, Idaho

by Walter L. Anderson

During the period $9 / 28 / 76$ to $10 / 11 / 76$, a small electromagnetic (EM) controlled source survey was conducted in the Raft River Valley, near Malta, Idaho. The purpose of the survey was: (1) to fleld test U.S. Geological Survey extra-low-frequency (ELF) equipment using a grounded wire source and recelver loop configuration (which is designed to measure the vertical magnetic field ( $\mathrm{Hz}$ ) at the loop center for various frequencies); (2) to present an example of the EM sounding data and interpretations using the inversion program developed by Anderson (1977); and (3) to graphically compare the EM results with DC Schlumberger results, obtalned by Zohdy, et.al. (1975), and Zohdy and Bisdorf (1976), for a geothermal environment.

Five ELF frequency soundings were made using a grounded wire source with a minimum length of 1480 meters and a maximum length of 3057 meters. The grounded (square) receiver loop was approximately 30 meters per side for all stations. These soundings were made with a minimum separation (between the line source and loop) of 250 meters and a maximum separation of 1003 meters. The maximum frequency range for each sounding was from 1 hertz to 2000 hertz, with 1.2 polnts per decade (some repeated points were used, and some points were deleted due to erronous observations).

Figure 1 shows the location of the five EM stations: EM1251, EM1252, EM1253, EM224, and EM225. The orientation of the wire source is indicated by a hachured line, and the center of the receiver loop is denoted by an 0 . Other numbers in figure 1 represent DC station numbers, where the DC results have been published by zohdy et.al. (1975) for numbers 1 to 136, and Zohdy and B1sdorf (1976) for numbers 137 to 219.

The observed amplitude and phase frequency soundings were adjusted at each EM station using predetermined equipment calibration curves. This was followed by normalizing the amplitudes by the primary tz field, and making linear phase drift corrections. The appendix shows the adjusted observed values plotted at the bottom of the symbols "O". 

The least squares EM station results, obtained by an Inversion program by Anderson (1977), are given in sets of three plots in the appendix - least squares phase solution with residuals, least squares amplitude solution with residuals, and the EM layer solution superimposed over the nearest DC layer solution (taken from Zohdy, et.al. 1975, and/or Zohdy and Bisdorf, 1976). The notation "model 6.5", for example, denotes a 6-layer model, version 5 .

The inversion program (Anderson, 1977) was run for each EM station independently, but both amplitude and phase data were used simultaneously in the least squares method. Some minor weighting of the data was done. Comparison of the EM and DC results is generally falr, considering the relative poor positioning of the EM and DC stations. Ideal station positions were not possible due to local effects (i.e., roads, power lines, burled cables, etc).

An attempt to compare numerical or statistical bounds for EM and DC layer solutions was not done, since statistical information is not available for the DC solutions. However, all EM station results generally showed less resolvability of the deeper layer parameters over the upper layer parameters; this qualitative pattern would be expected for the frequency range and separations used.

The calculations were done using the cyber 74-28 and Honeywell $68 / 80$ computer systems*, and the plots were produced using an AJ832 terminal (plot resolution 1/60 inch $x$-direction, $1 / 40$ inch $y$-direction).

* Use of brand names in this report is for descriptive purposes only and in no way constitutes endorsement by the U.S. Geological Survey. 


\section{References}

Anderson, W.L., 1977, Marquardt inversion of vertical magnetic field measurements from a grounded wire source: U.S. Geo1. Survey Rept. USGS-GD-77-033, 76p. available from U.S. Dept. Comm. Natl. Tech. Inf. Service, Springfield, Va., 22161 as Rept. PB-263-924/AS.

Zohdy, A.A.R, Jackson, D.B, B1sdorf, R.J., 1975, Schiumberger soundings and total field measurements in the Raft River geothermal area, Idaho: U.S. Geol. Survey Open-File Rept. $75-130,5$ p., +136 text figures, +3 pl.

Zohdy, A.A.R., and Bisdorf, R.J., 1976, Schlumberger soundings in the upper Raft River, and Raft River valleys, Idaho and Utah: U.S. Geol. Survey Open-File Rept. 76-92, 6 p., +71 text figures, +1 p 1 . 


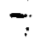

Appendix

Page 6 


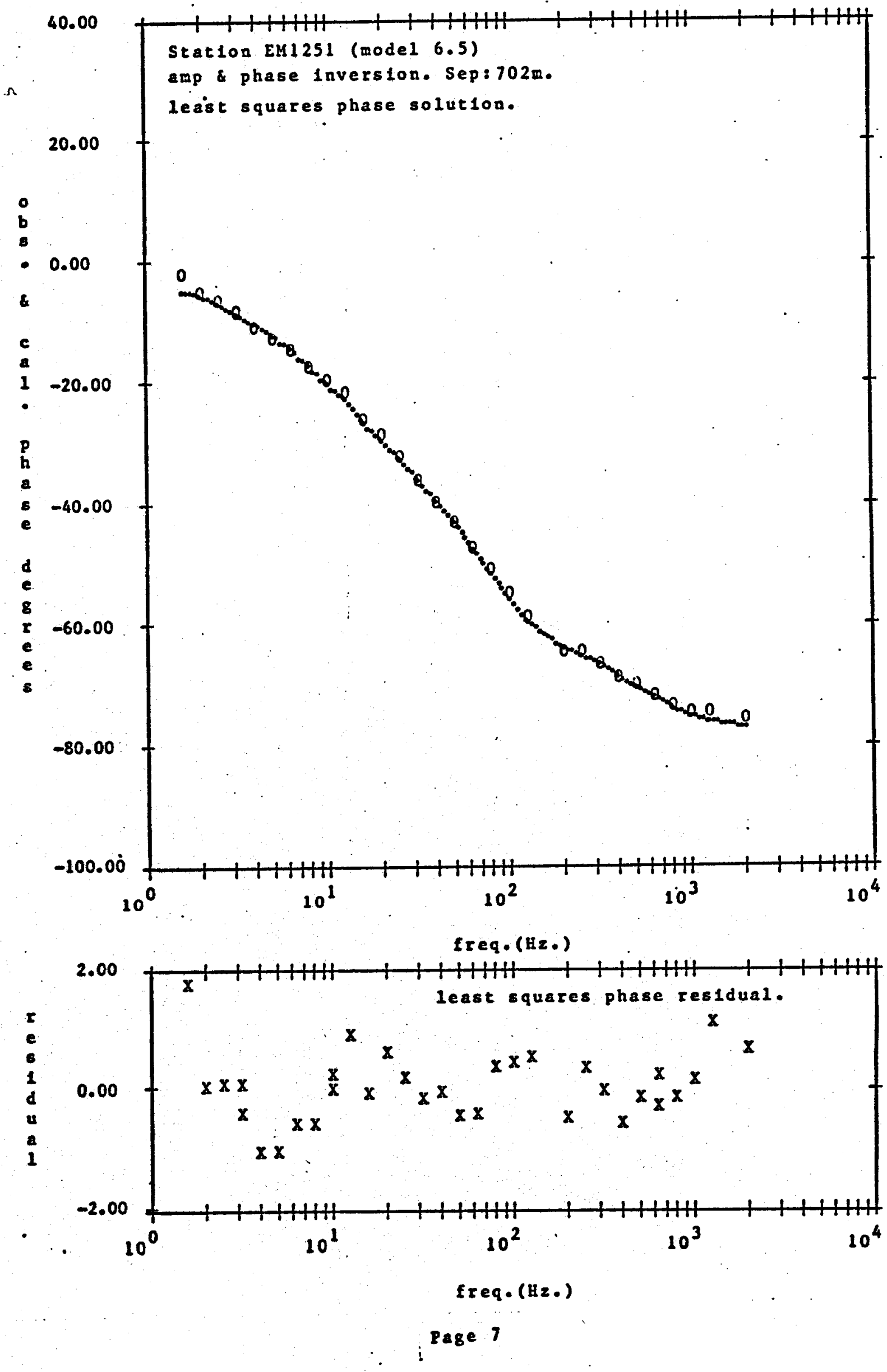



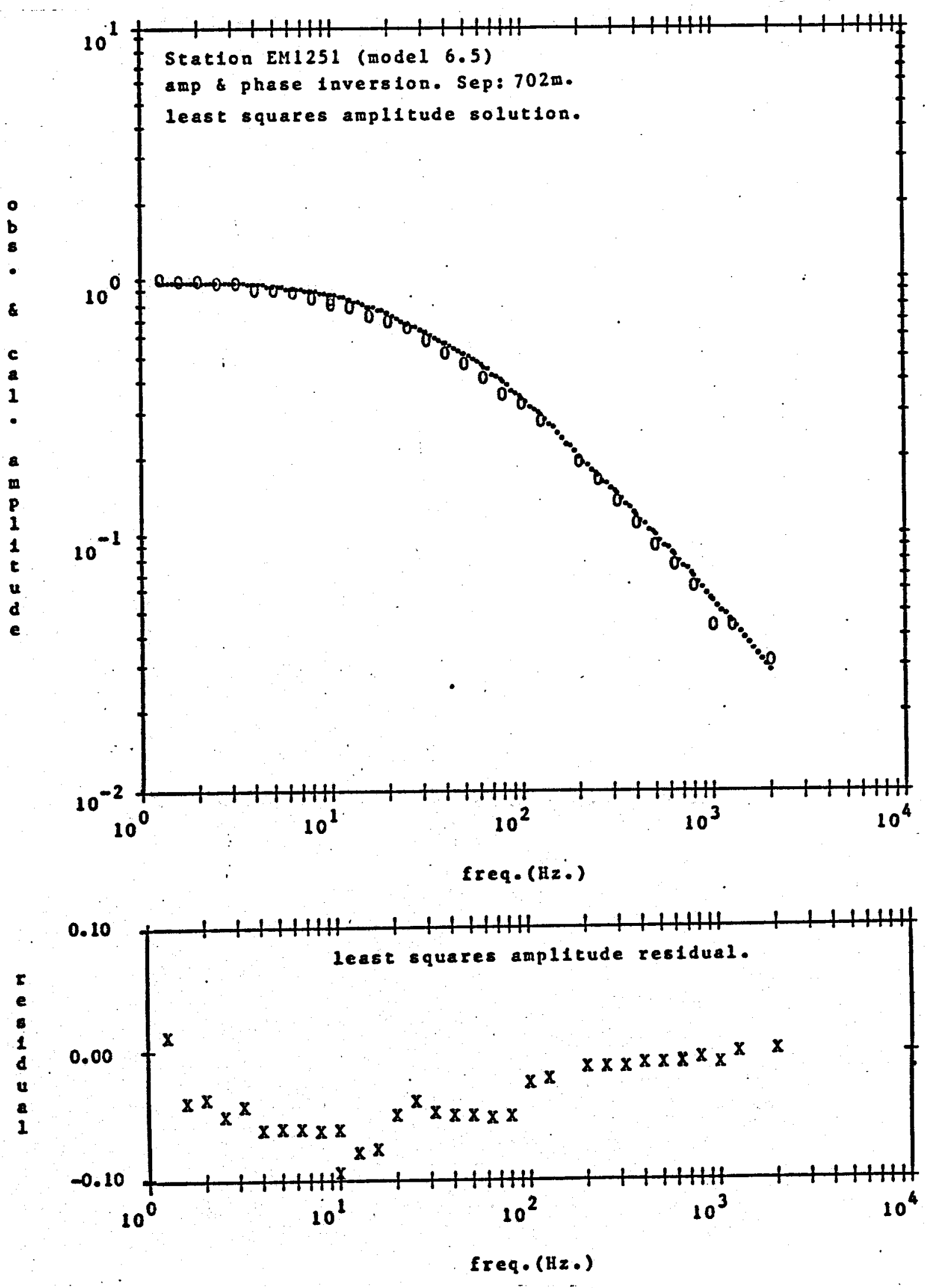


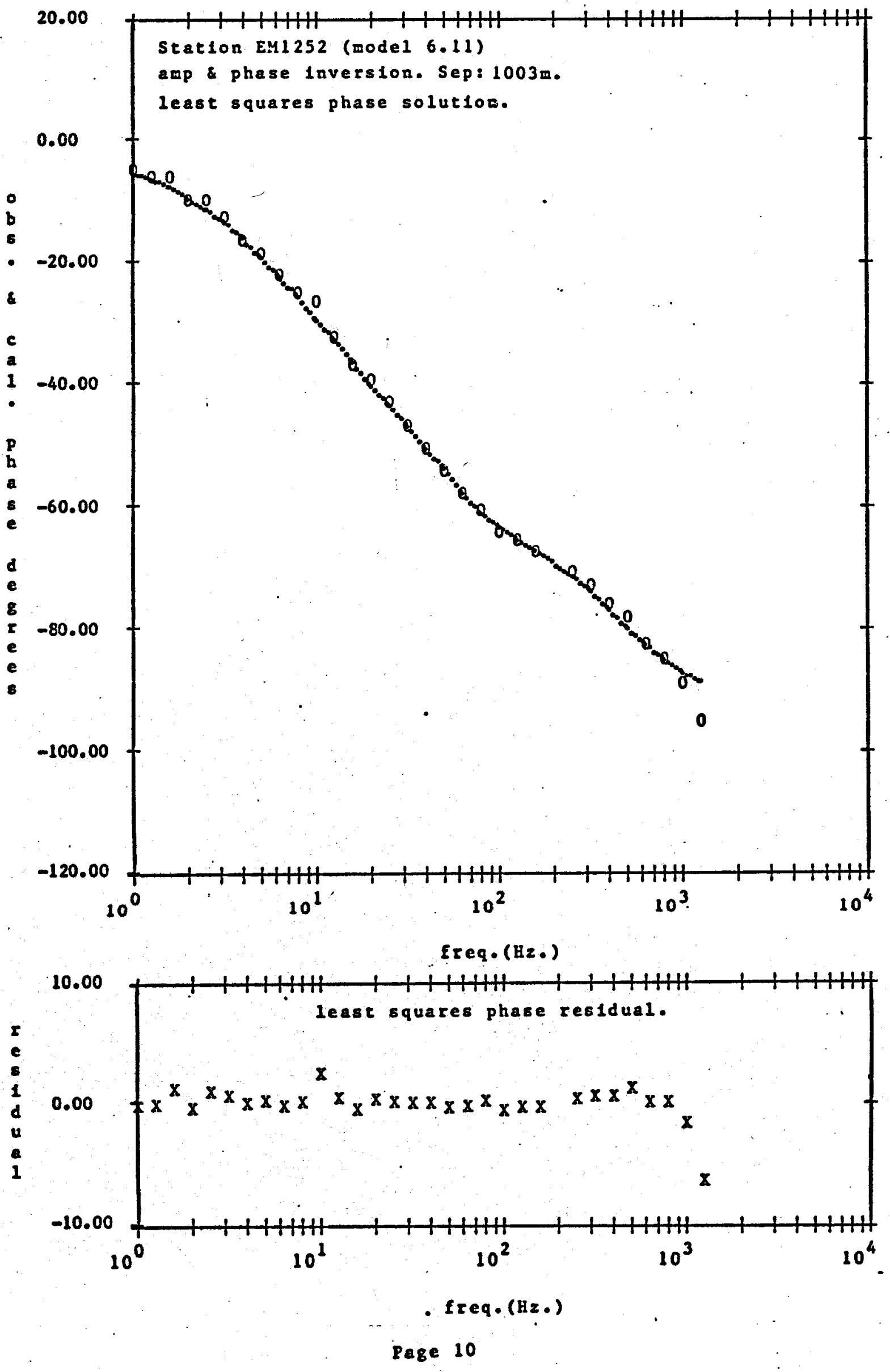



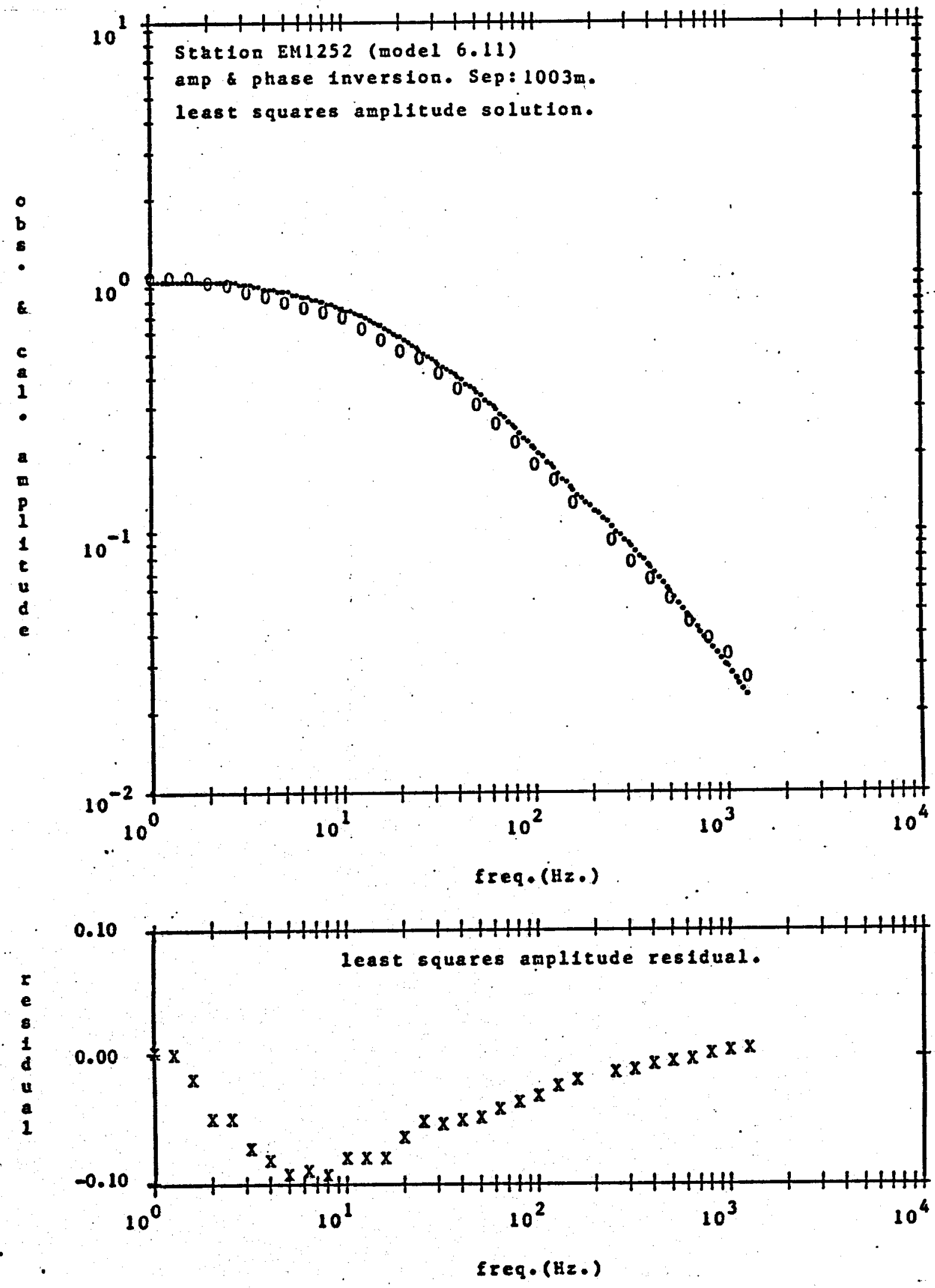

Page 11 


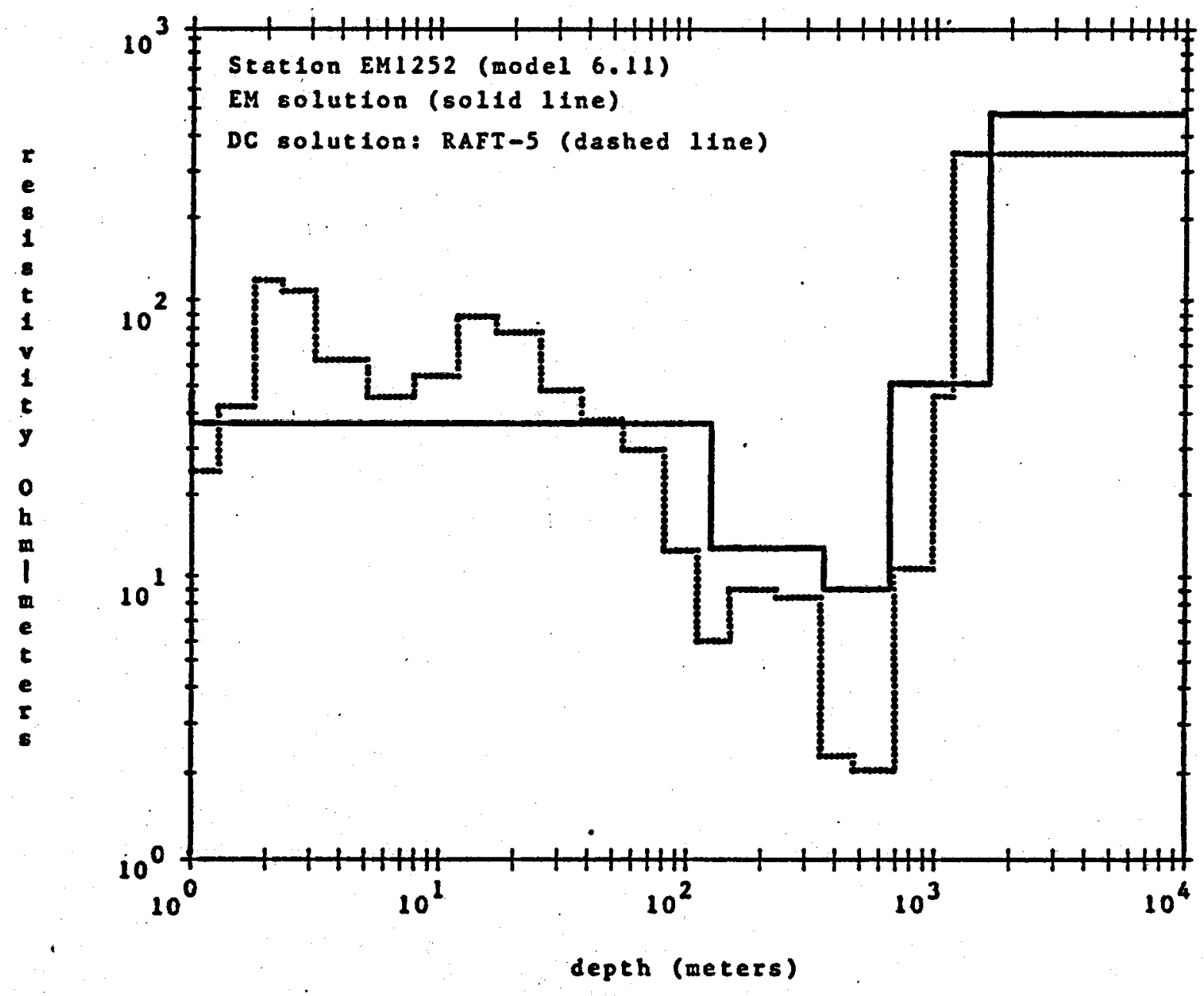

Page 12 


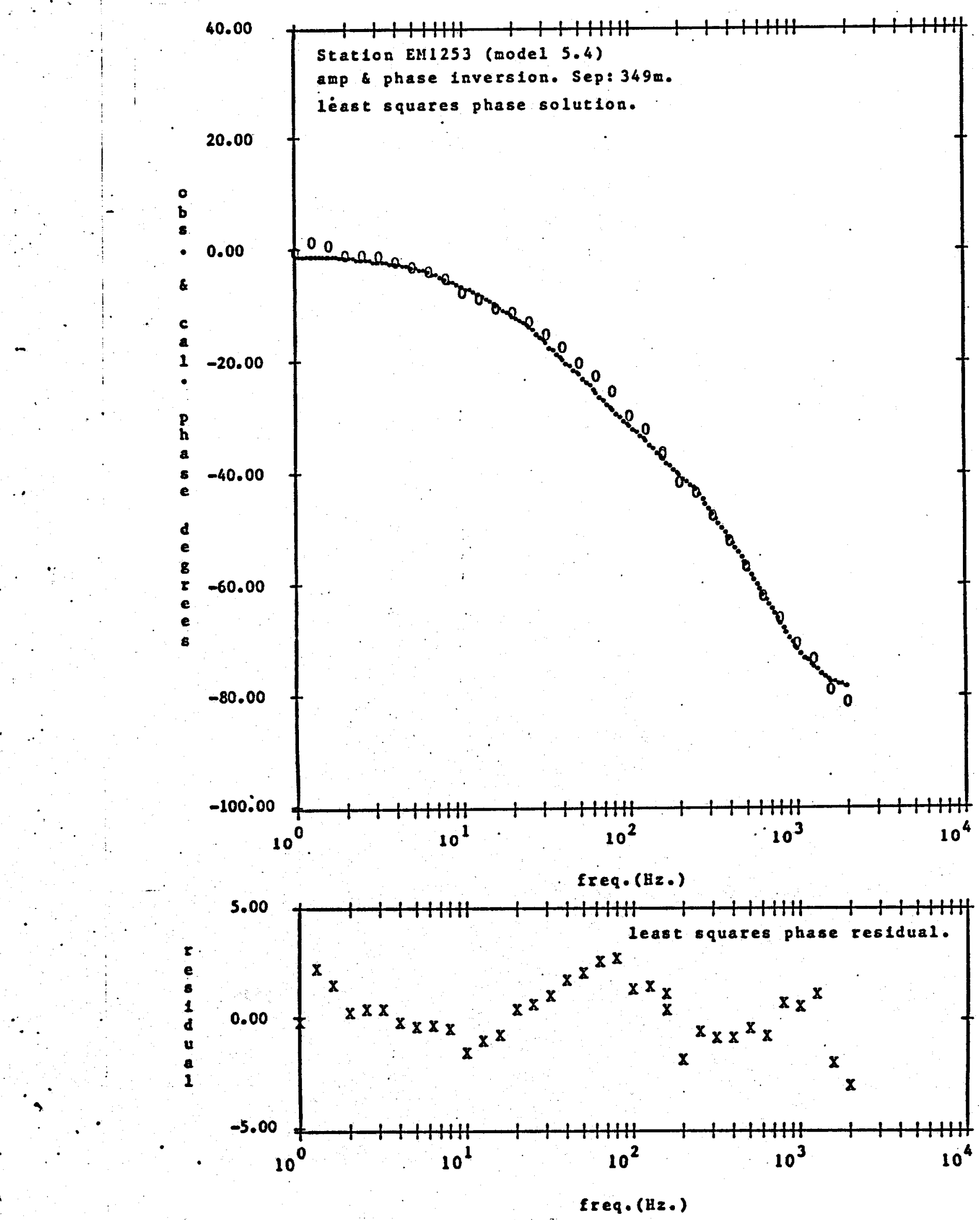



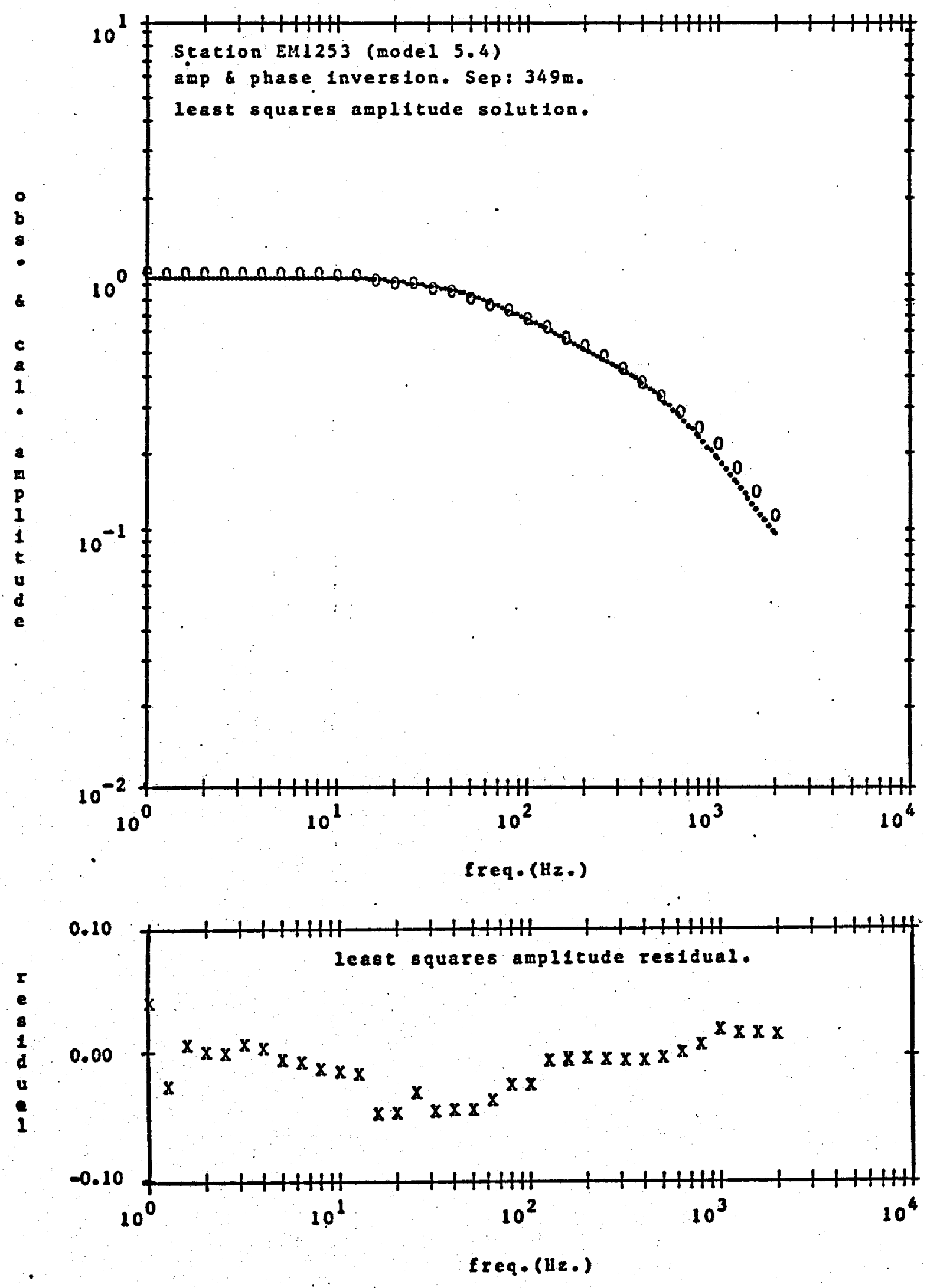


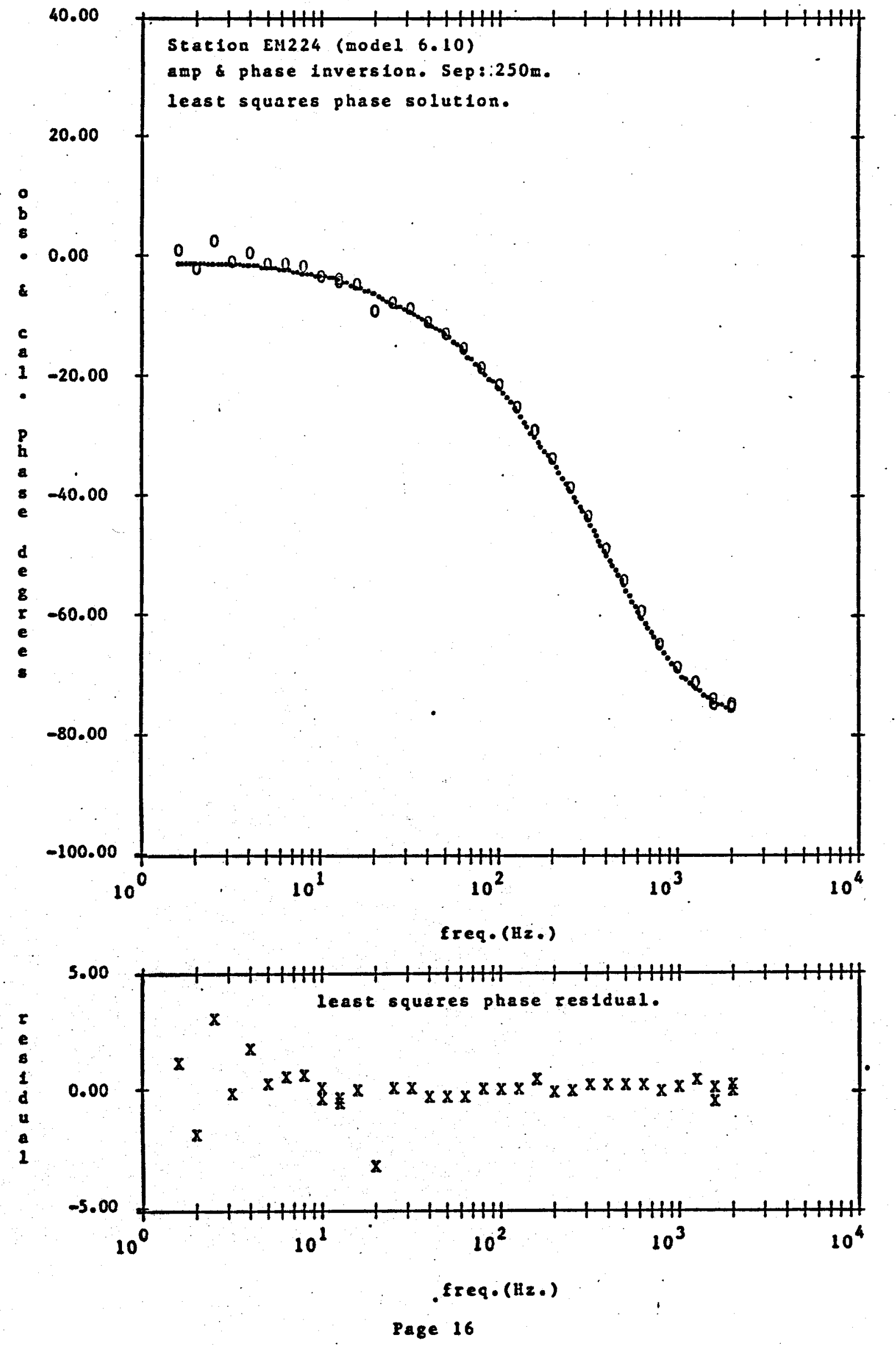



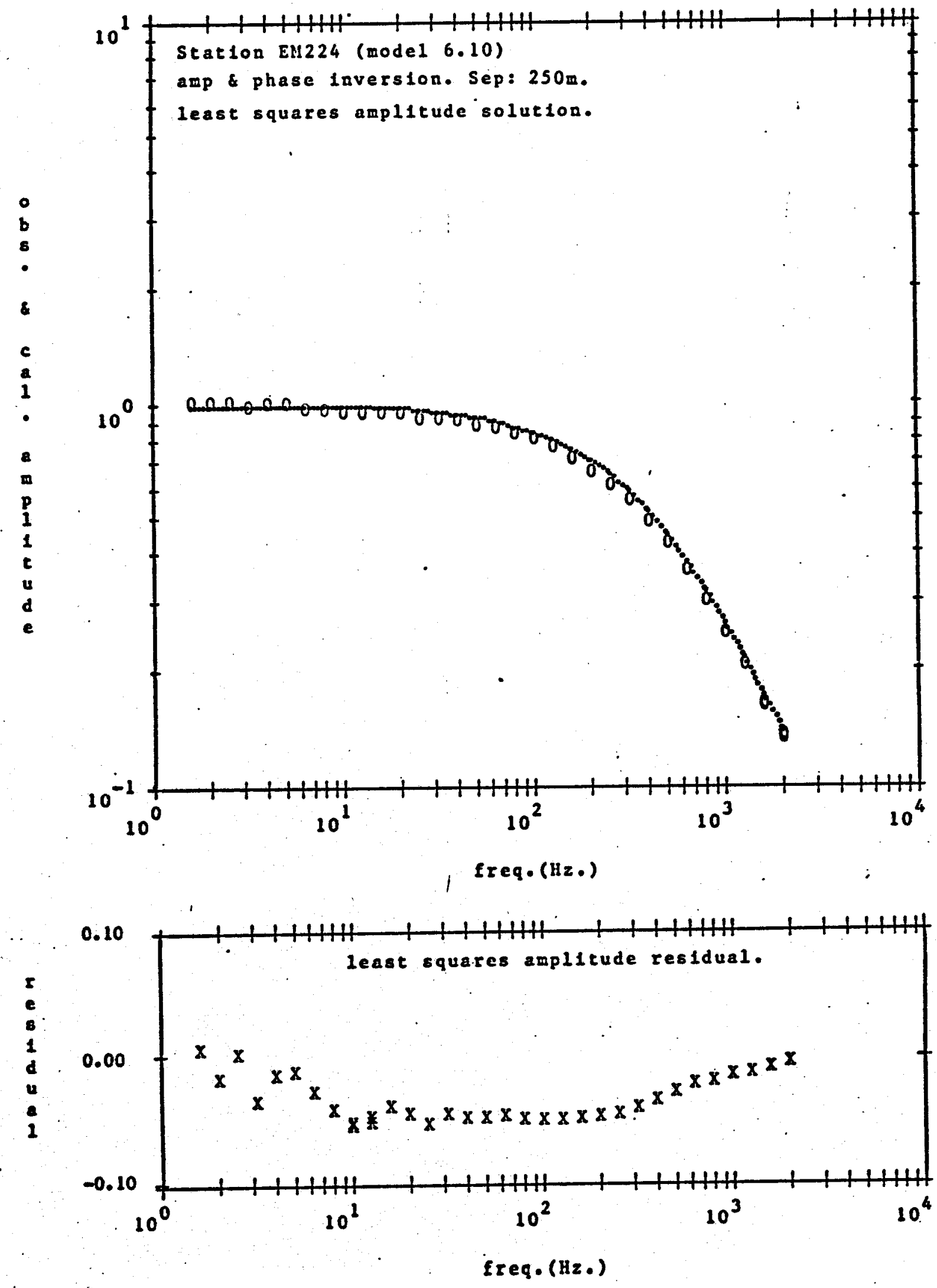



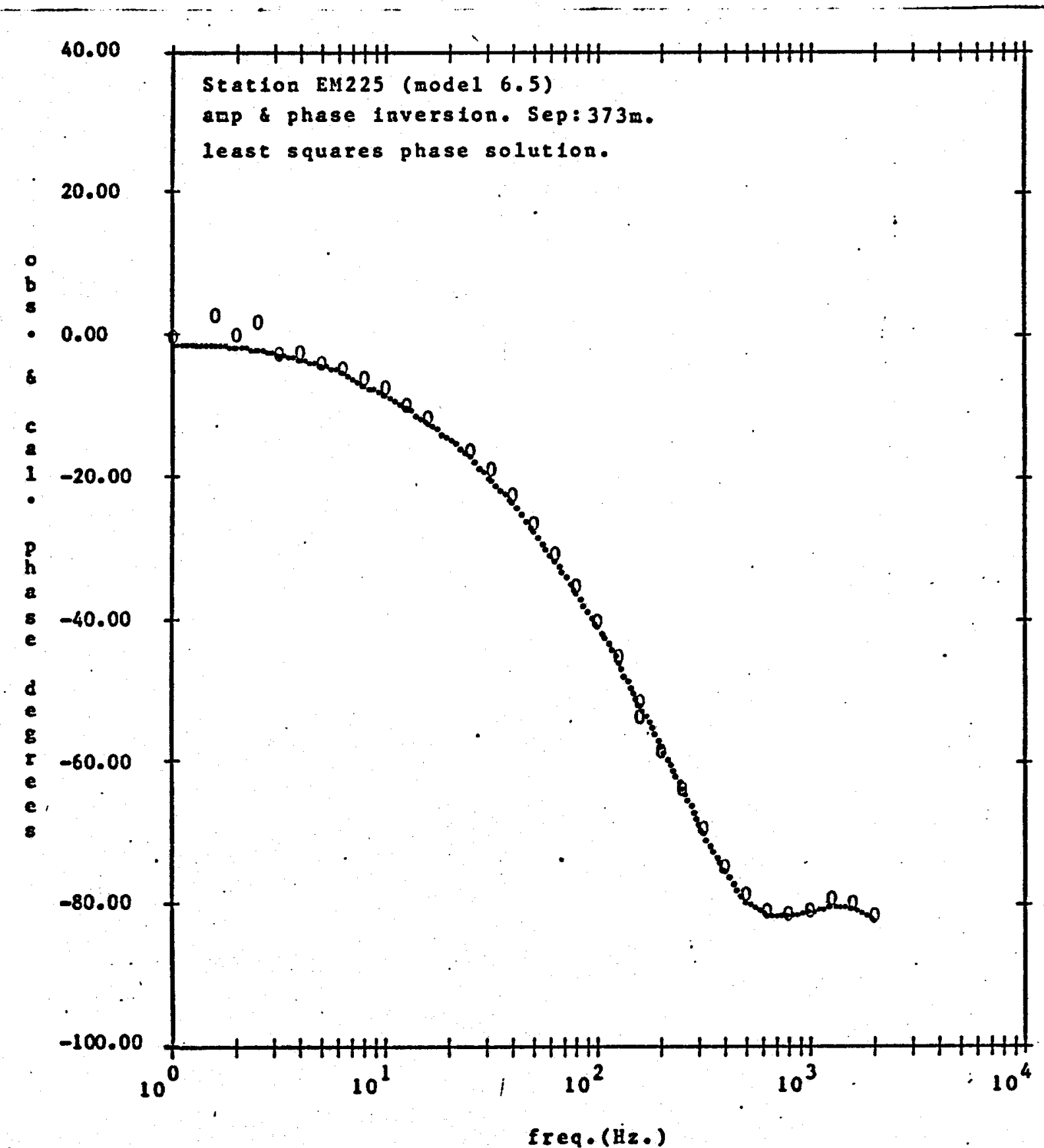

freq. (Hz०)

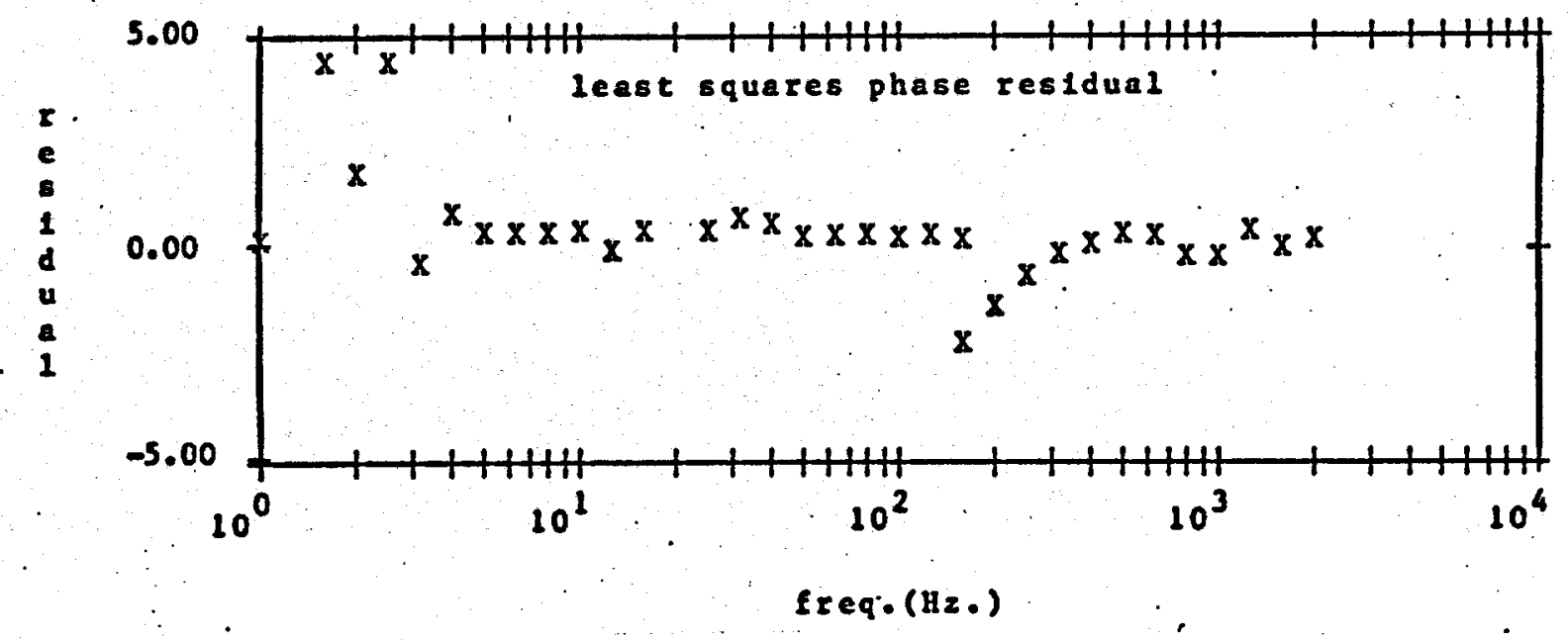





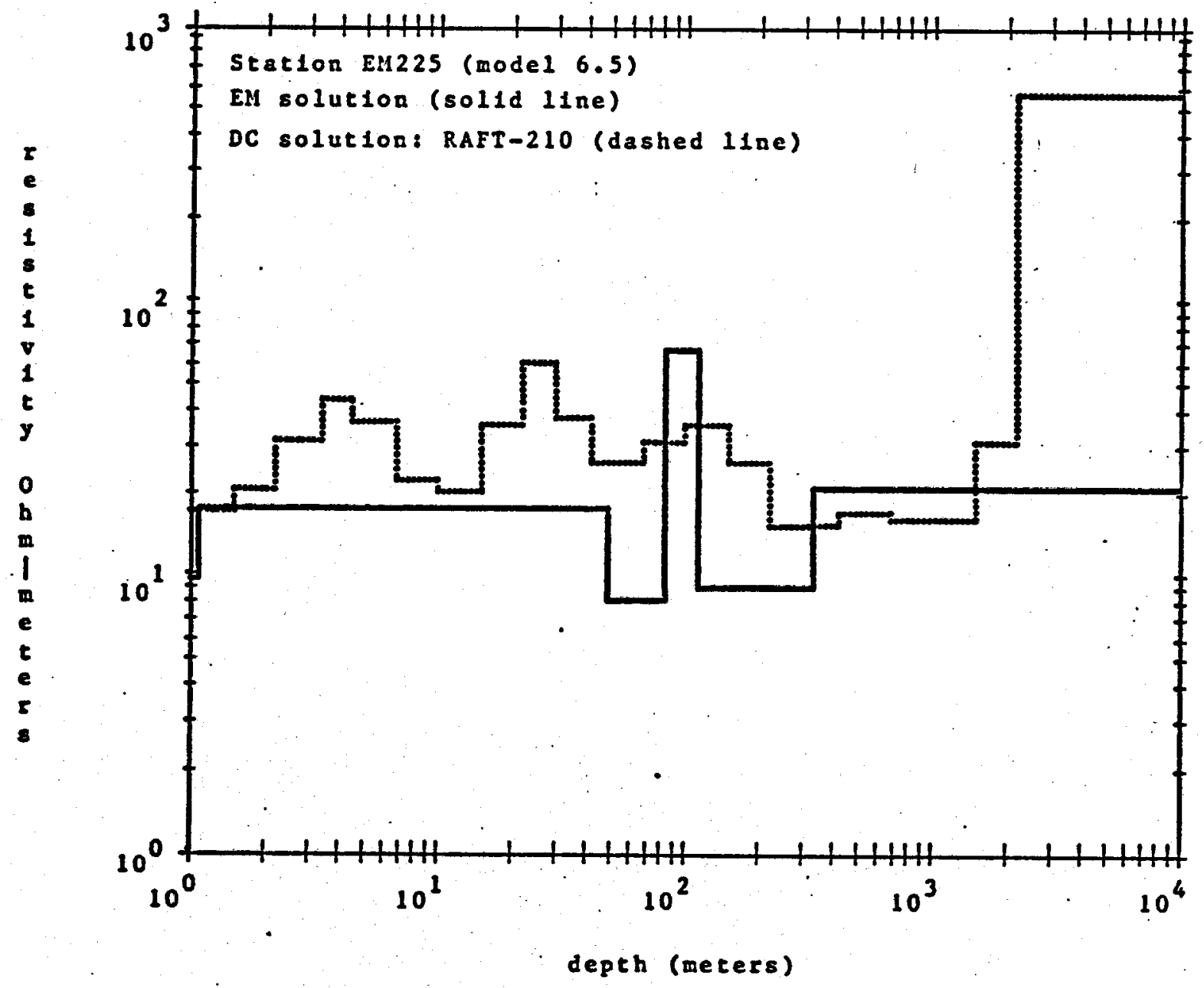

Page 21 